\title{
SAR干渉画像を用いた能登半島地震及び中越沖地震に伴う地表変動の解析 \\ Analysis of surface deformation induced by the Noto Hanto and the Chuetsu-oki \\ Earthquakes in 2007 using synthetic aperture radar interferograms
}

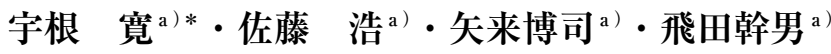 \\ Hiroshi UNE, Hiroshi P. SATO, Hiroshi YARAI and Mikio TOBITA
}

\begin{abstract}
The launch of the Advanced Land Observing Satellite 'Daichi' enabled us to detect the deformation of the land surfaces in detail with its high-resolution synthetic aperture radar sensor. We have observed a number of characteristic patterns reflecting the local surface deformation in an interferogram processed to detect the surface deformation triggered by the Noto Hanto Earthquake in 2007, which indicate the slight movements of landslides accompanied with the seismic motion. We processed an interferogram for Chuetsu-oki Earthquake in 2007 as well, and found several pattaerns suggesting the occurrences of subsidence and lateral flow of the soil. Thus, SAR interferograms can provide important information for monitoring of further development of deformation and planning of countermeasures.

Key words : synthetic aperture radar, interferometry, Advanced Land Observing Satellite 'Daichi', earthquake, surface deformation

\section{和文要旨}

陸域観測技術衛星「だいち」に搭載された合成開ロレーダー（SAR）は，これまでになく高い分解能で地表の変動を捉えること ができる。能登半島地震に伴う地表変動を解析したSAR干渉画像には，局所的な地表の変動を反映した微小な変化パターンが多数 みられ, 地震動に伴うわずかな地すべり性の変動を捉えていることが明らかとなった。一方, 中越沖地震についても同様な解析を 行ったところ，地盤の沈下や側方流動を示唆するパターンが現れた。このように，SAR干渉画像は，さらなる变状の監視や防災対 策立案のための, きわめて有効な情報を提供することが明らかになった。

キーワード : 合成開ロレーダー, 干渉解析, 陸域観測技術衛星「だいち」, 地震, 地表変動
\end{abstract}

\section{1.はじめに}

干渉合成開口レーダー（干渉SAR）は，地表面の変 動を面的に把握する技術として, 地震時の地殸変動の解 明や火山活動に伴う火山体の変動, 地盤地下の広がりの 把握など，すでに多くの実績がある。

干渉SARを用いて地すべりの変動を検出する試みも 行われており，わが国では，八幡平や遠音別岳の地すべ りや兵庫県南部地震における芦屋断層付近の地すべりを 検出した事例が報告されている（矢来ほか2004, 関口ほ か2005）が，良好な成果が得られた事例は多くない。清 水ほか（2005）は, 干渉SARによる地すべり地検知の 可能性について, 現状と課題をまとめているが, 良好な 結果が得られない原因として, 干渉画像の干渉性(コヒー レンス）の問題が考えられるとし，分解能が高く，精密 な軌道情報が得られるわが国の陸域観測技術衛星（打ち 上げ後「だいち」と命名された。）のLバンドのSARに より,コヒーレンスが大幅に改善され，広域にわたる地 すべり検知の可能性が高まるとしている。

また，海外でも，イタリア，スイス，アイスランドな どのヨーロッパ諸国や，米国，ニュージーランドなど， 多くの地すべり抽出事例の報告がある (Hilley et al., 2004など)。しかしながら, 海外の事例の多くはENVI-

* 連絡著者/corresponding author

a) 国土地理院

Geographical Survey Institute

厂 $305-0811$ 茨城県つくば市北郷 1

1, Kitasato, Tsukuba, Ibaraki, 305-0811 Japan
SAT（欧州宇宙機関が運用する環境観測衛星）やRADARSAT（カナダが運用する商用レーダー衛星）に搭 載されたCバンドのSARを用いていることから, 特に植 生のある山間部などではコヒーレンスが不十分で，面的 な干渉画像を得ることができない。このため, 長期にわ たる観測デー夕を用いて, 後方散乱特性の時間的変化が 少ない多数の点の移動量を求める定常散乱体干渉SAR (PSInSAR）の手法を用いて変動の抽出を行っている例 が多い。Refice et al, 2000)は, 地すべりのような小 領域の現象を対象とした解析では, 変動の範囲が大きい こと, 植生がまばらなこと, 変動が緩慢であることなど の特殊な環境のもとで, 基線長の短い, 適当な視線方向 の，降雨直後でないSAR画像のペアが得られた場合の み良好な結果が得られるとしている。

2006年 1 月に打ち上げられた陸域観測技術衛星「だい ち」に搭載されたPALSARは, 清水ほか（2005）が予 想したように, 干渉性が極めて高く, 高い分解能で地表 の変動を捉えた画像を提供している。すでに，2006年11 月から活発化した硫黄島の火山性地款変動や，2007年 3 月の能登半島地震, 2007 年 7 月の新潟県中越沖地震など に伴う地款変動を詳細に明らかにし, 地震断層の推定な どに大きく貢献している（国土地理院，2007a，b，c， 地震調查研究推進本部, 2008)。さらに, 国土地理院で は，「だいち」を利用した干渉SARにより，日本全国の 地表変動を常時監視する体制の整備を進めている。 
本稿では，「だいち」のPALSARにより，地震時のわ ずかな地すべりや地盤の変動を検出することができるよ うになったことを示し，地表変動の新たな検出手段とし ての干渉SARの可能性がきわめて大きいことを述べる。

\section{SAR干渉画像にあらわれた能登半島地震の地表変動 2.1 SAR干渉画像の特徴}

合成開ロレーダー（SAR）は，人工衛星や航空機か ら地表に向けてマイクロ波を発射し，その反射波を観測 することにより地表面の性状を把握する技術である。干 渉SARは，地表の同一の地点のSAR観測を 2 回行い, 衛星や航空機と地表との間の距離の変化によって生じる 反射波の位相のずれを干渉画像として捉えることによ り，2回の観測の間に発生した地表面の変動を面的に把 握する技術である。SARに用いられるマイクロ波は， 主にXバンド (波長約 $3 \mathrm{~cm})$, Cバンド $($ 約 $6 \mathrm{~cm}), \mathrm{L}$ バ ンド（約 $24 \mathrm{~cm} ）$ があり，波長が短いほど解像度は高い が，コヒーレンスは低下する。特に，植生に覆われてい る地域では，XバンドやCバンドではほとんど干渉画像 を得ることができない。「だいち」に搭載されているPALSARは，現在運用されている唯一のLバンドSARである。

干渉SARでは，地表面の変動を反映した縞模様のSAR 干渉画像が得られる。干渉画像上の青 $\rightarrow$ 赤 $\rightarrow$ 黄 $\rightarrow$ 緑 $\rightarrow$ 青 （もしくはその逆）の一回りの色の変化は，2回の観測の 間に半波長分の距離の変化があったことを示す。「だい ち」のPALSARの波長は $23.6 \mathrm{~cm}$ であるので，1周期の干 渉縞は $11.8 \mathrm{~cm}$ の距離の変化を示していることになる。 通常, 青 $\rightarrow$ 赤 $\rightarrow$ 黄 $\rightarrow$ 緑 $\rightarrow$ 青の変化は衛星から地表が遠ざ かり, 青 $\rightarrow$ 緑 $\rightarrow$ 黄 $\rightarrow$ 赤 $\rightarrow$ 青の変化は衛星に地表が近づい たことを表す。

また，衛星SARでは，電波が衛星から斜め下方に向 かって発射される。「だいち」はほほ南北の極軌道をもっ ているため, 衛星が南から北に通過する（ascending軌 道) 際には西方上空から，北から南に通過する (descending軌道）際には東方上空から対象地域を観測する。南 北方向の水平移動に対しては感度がない。「だいち」は 46日周期で同じ軌道を通過するため, SAR干渉画像が 得られる最短の間隔は46日である。

なお，干渉SARのしくみやSAR干渉画像の見方など については，すでに多くの解説がある（国土地理院干渉 SARホームページ（国土地理院，2008）など)。

\section{2 地殼変動差分画像の作成}

2007 年 3 月 25 日 9 時 41 分，能登半島西岸付近の深さ約 $10 \mathrm{~km}$ でマグニチュード 6.9 の地震が発生し, 最大震度 6 強が観測された（平成19年（2007年）能登半島地震)。 この地震により死者 1 名のほか, 多数の家屋が全壊する など，大きな被害が発生した。国土地理院では，この地 震に伴う地殸変動を「だいち」のSAR干渉画像により 解析し, 精度の高い震源断層モデルの推定を行った（雨 貝ほか，2007）が，SAR干渉画像には，断層運動によ
る広域の弾性的変形に加えて, 局所的な地表の変動を反 映した微小な変動パターンが多数みられた。筆者らは, これらは地震動に伴う数 $\mathrm{cm}$ 数 $10 \mathrm{~cm}$ のわずかな地すべ り性の変状が捉えられている可能性があると考え，これ を実証するため，調查・解析を行った。

SAR干渉画像には，地下の断層運動による広域的な 弾性変形と，地すべりなどの局所的な表層の変状が合成 された変動が記録されていると考えることができる。こ のため, SAR干渉画像から，震源断層モデルをもとに 計算した広域的な弾性変形のシミュレーション結果を取 り除いた差分画像を作成した。

図 - 1 は，地震前の 2007 年 2 月 23 日と地震後の 4 月 10 日に対象地域の西方上空から観測されたPALSARの データを用いて作成されたSAR干渉画像である。図一 2 は，図-19画像に最も適合するように推定された震 源断層モデル（図-3，小沢ほか，2007）から地表の地 殼変動量を計算し，その值をもとに，図-1の条件（軌 道, 視線方向)のもとで観測されるべき干渉画像のシミュ レーションを行ったものである。画素ごとに，図-1の 值から図-2の值を取り除くことにより作成した画像が 地款変動差分画像（図-4）である。

さらに，地表変動と，地形や地物との関係を明確にす るために，この画像を電子国土webシステムに載せ，地 形図と重ねて表示できるようにした（http://zgate. gsi. go. jp/notojishin/notojishin. html)。

\section{3 地表変動の認定と現地での確認}

地殸変動差分画像を詳細に観察したところ，さまざま な変動パターンが判読された。中でも, 山間部に, 長さ · 幅が数 $100 \mathrm{~m}$ 程度の棈円形や馬蹄形のパターンが多数見 られた。変動量は干渉縞 $1 \sim 2$ 周期分，すなわち衛星視 線方向数 $\mathrm{cm}$ から $20 \mathrm{~cm}$ 程度のものが多い。

この画像を防災科学技術研究所の地すべり地形分布図 のデー夕（防災科学技術研究所，2007）と重ね合わせた ところ, 変動パターンの多くは地すべり地形の分布と一 致し，推定される変動の向きも概ね地形と整合的，すな わち，地すべり移動域の沈下もしくは最大傾斜方向への 水平移動を示す変動であった。

筆者らは，このうちの数力所を現地踏査した。輪島市 門前町俊兼（図－5）では，既存の地すべり地形をなぞ るように馬蹄形の変動パターンが現れた。周辺が一様に 青を示す中で，変動域は黄色〜赤を示していることから， この範囲全体が西方上空の衛星の方向に数 $\mathrm{cm}$ 近づいた ことが示されている。すなわち地盤が西方向に数 $\mathrm{cm}$ 移 動したか，もしくは数 $\mathrm{cm}$ 隆起したことを示す。地形か らみると，東南東から西北西に向かう地すべりと考えら れるから，この変動パターンが地すべりの再滑動を示し ているとすると，地盤が隆起したことは考えにくく，西 方向への移動と考えられる。現地踏査の結果, 変動パター ンから滑落崖が想定される場所で，地震時に発生したと 判断できる約 $10 \mathrm{~cm}$ の段差が地表に発見された (写真 -1$)$ 。 



Analysis by GSI from ALOS raw data @METI, JAXA

図ー2＼cjkstart断層モデルによる 干渉画像シミュ レーション

Fig. 2 Expected interferogram from fault model

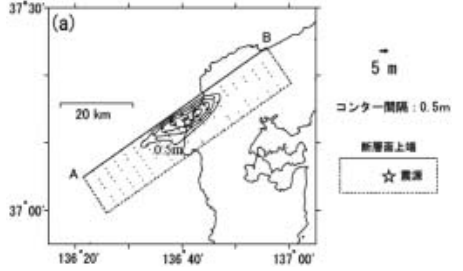

図ー 3 震源断層モデル（小沢ほか2007）

Fig. 3 Seismic fault model

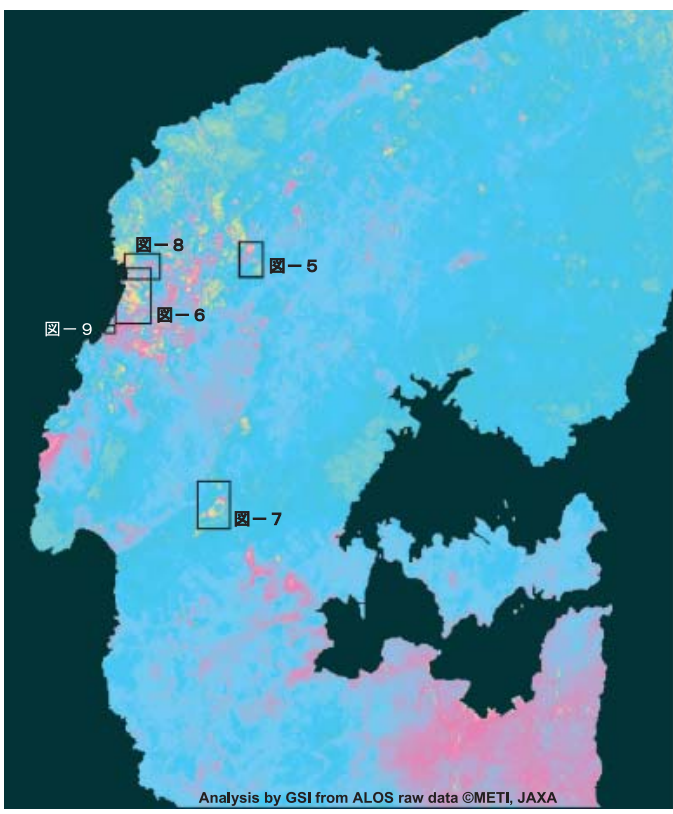

図一４地殼変動差分画像

Fig. 4 Residual interferogram

従って，この変動パターンは地震動で地表が西方向に移 動したことを示していると考えられる。

図- 6 は，輪島市門前町大生の変動パターンである。 既存の地すべり地形の範囲にほぼ対応するように変動パ

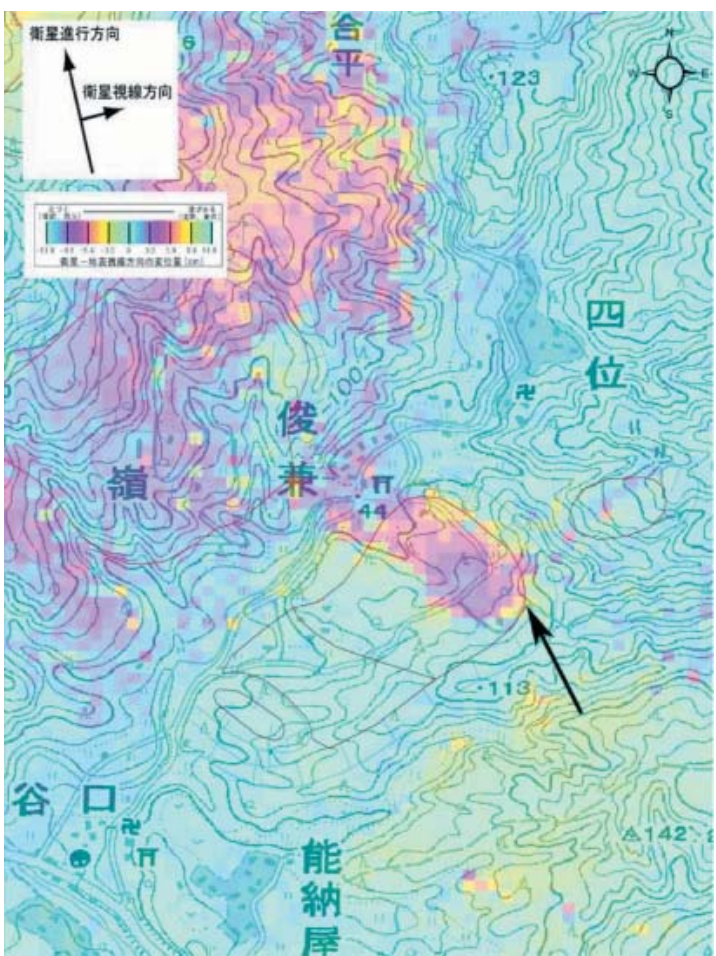

図ー 5 輪島市門前町俊兼の変動パターン

Fig. 5 Deformation pattern in Toshikane

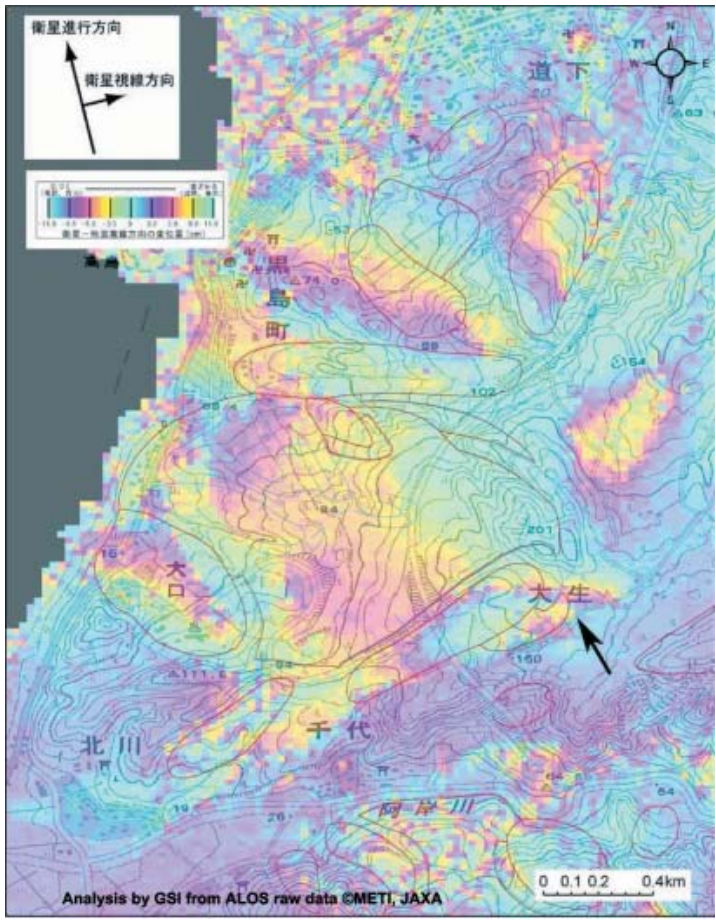

図ー6 輪島市門前町大生の変動パターン

Fig. 6 Deformation pattern in Ohae

ターンが現れている。矢印に示した地点には，周辺の青 〜青紫の範囲からみて黄 $\rightarrow$ 赤 $\rightarrow$ 青のサイクル 2 回分の干 涉縞が現れており，縞の南側は北側に比べて $20 \mathrm{~cm}$ 程度 西方上空の衛星に近づいたと判読できる。現地では道路 
上の亀裂や斜面変動による樹木の転倒などが観察され (写真 -2$)$, 斜面が西に移動していることが明らかと なった。このため，ここでも地震時の地表の変動が変動 パターンに示されていると考えられる。

また，まったく既存の地すべり地形がみられない地点 に明瞭な変動パターンが現れた場合もあった。七尾市中 島町古江には，幅約 $1.5 \mathrm{~km} ，$ 奥行約 $700 \mathrm{~m}$ の楕円形の明 瞭な変動パターンが現れた（図一 $7-1$ )。地形的には 過去の地すべりを示す特徴はなく，また，いくつかの尾 根や谷を越えてパターンが広がっている。この変動をよ り詳細に把握するため，Fujiwara et al.(2000) の手法 を用いて，異なる軌道からの 2 組のSAR干渉画像を解 析し，変動を上下方向と東西方向の成分に分離（2.5 次 元化）した。2006年12月23日と2007年 5 月10日に対象地 域の東方上空から観測したデー夕を用いてSAR干渉画 像を作成し，上述の西方上空より観測した干涉画像と組 み合わせて変動べクトルの解析を行い, 上下方向（図一 $7-2$ ) と東西方向（図－7-3）のそれぞれの移動量 の分布を求めた。さらに，これをもとに最大の変動を示 す地点を通る東西断面の変動べクトルを求めた（図 -7 -4）ところ，中島町古江では，地すべりの構造から想 定される変動パターンとよく整合する地表変動を示す結 果が得られた。現地踏査では地表に亀裂等の顕著な地す ベりの兆候を発見することはできなかったが，楕円形の ブロック全体が移動するすべり量最大数 $10 \mathrm{~cm}$ 程度の初 生的地すべりが発生していたことが推定される。

なお，地震後のSAR干渉画像では，この地すべりに 伴う変動は観測されておらず，地震時のみに活動したと 考えている。

一方, 現地調查や空中写真判読から明らかに地すべり や斜面崩壊が認められる地点に, 差分画像では変動パ ターンが表れていない場合もあった。これは，地すべり や斜面崩壊の範囲が狭かったこと，地形変化が大きすぎ てSARが干渉しなかったことなどにより，変状の情報 が得られなかったためと考えられる。

\section{4 沖積層の沈下と砂丘の変形}

今回作成したSAR干渉画像による地款変動差分画像 は，このほかにもさまざまな地震に伴う非構造性の地形 変化を捉えている。

\subsection{1 輪島市門前町道下付近}

図 - 8 は，最も家屋倒壊などの被害が著しかった輪島 市門前町道下周辺の地殸変動差分画像である。図中Aで 示した地域では, 図の中央を西流する八ヶ川の沖積低地 の範囲が紫〜黄色を示していることから，周辺（青）よ り数 $\mathrm{cm}$ 衛星から遠ざかっていることがわかる。これは, 地震動により未固結の沖積層（砂質沖積層。石川県, 1991）が液状化もしくは圧密により沈下したものと考え られる。実際, この地域では, 地震後, 橋やカルバート, マンホールなどの地中の構造物が道路面などから抜け上 がる現象が多数見られたが，これは，沖積層の地盤が沈
下したことにより，基礎が比較的深い構造物が相対的に 地盤から抜け上がったために発生したものである。

また，全体的には青や紫の単調な色が示されている。 このことは，地盤に比較的一様な変動があったために SARの干渉が得られていることを示しているが，図中B から南の海岸に沿った帯状の地域には，さまざまな色の 画素が不規則に並び，干渉が得られていない。

石川県（1991）によると，この地域の地盤は小規模な 砂丘（八ヶ川河口域北岸）と沖積低地（八ヶ川河口域南 岸の沿海部）で形成されている。砂丘砂や未固結の砂質 沖積層が表層に分布する地域のみ干渉が得られていない ことは，砂質の地盤に地震動により不規則な地表の変形 が起こったことを示していると考えられる。

\subsection{2 輪島市門前町池田付近}

図 - 9 は，輪島市門前町池田付近（道下から南南西約 $3 \mathrm{~km} ）$ の地殸変動差分画像である。この図のほぼ中央 の集落付近が周辺の紫から青〜黄色に変化しており，局 所的に数 $\mathrm{cm}$ 西方上空の衛星に近づいたことが示されて いる。このような局所的な隆起があったことは考えにく いことから，集落全体が海側（西側）へ移動したと考え られる。池田の集落付近は，2つの河川の合流点の南側 に位置する。石川県（1991）は，池田集落の周辺を沖積 低地（砂質沖積層）及び砂丘と地形分類している。沖積 低地と砂丘は海側に $2^{\circ}$ と緩やかに傾斜しているが，集 落よりも山側には海側に $6^{\circ} \sim 10^{\circ}$ 傾斜する地すべり・崩 壊ブロックがある。すなわち，沖積低地と砂丘はこのブ ロックの末端部に位置している。図－9 を見ると，沖積 低地，砂丘に相当する部分が全体的に海側に移動する動 きを示しており，池田集落の立地する地盤ごと海側に側 方流動したと考えられる。集落内の家屋等に著しい被害 はみられず，ブロック状に移動したものと思われる。

\section{3. 中越沖地震の地表変動と被害}

能登半島地震から 4 ケ月足らずの 2007 年 7 月 16 日 10 時 13分，新潟県上中越沖の深さ約 $10 \mathrm{~km}$ でマグニチュード 6.80 地震が発生し，最大震度 6 強が観測された（平成 19 年（2007年）新潟県中越沖地震）。この地震により死 者15名のほか，柏崎市街地を中心に家屋が多数全壊する など，大きな被害が発生した。その被害の特徴としては， 地震の規模と地質的条件が2004年の中越地震と比較的似 ているにもかかわらず，多数の斜面崩壊や地すべりが発 生した中越地震と異なり，斜面崩壊，地すべりの発生が 比較的少なかったことと，砂丘の縁辺部，旧河道，自然 堤防など，特定の地形条件をもつ地域に被害が集中した ことがあげられる。

本稿では，被害の要因となった地震に伴う地形変化を 「だいち」のSAR干渉画像で抽出し，被害，地形変化の 分布と地形条件の関係について考察することを試みた。

\section{1 SAR干渉画像とその判読}

図 -10 は，地震前の 2007 年 6 月 14 日と地震後の 9 月 14 


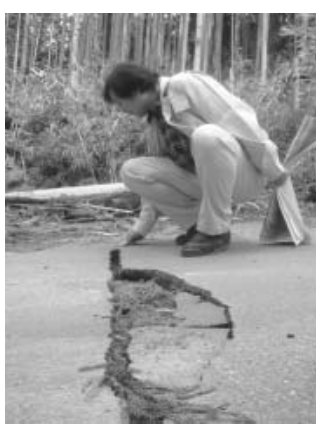

写真一 1 地すべりによる道路 上の亀裂（図一 5 の 矢印の地点）

Photo 1 Cracks on road inferred by landslide

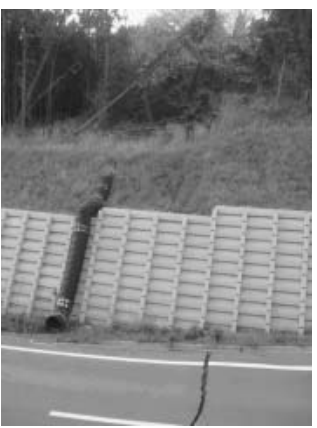

写真一 2 地すべりによる道路 上の亀裂, 斜面の変 状（図一 6 の矢印の 地点）

Photo 2 Cracks and slope deformation inferred by landslide

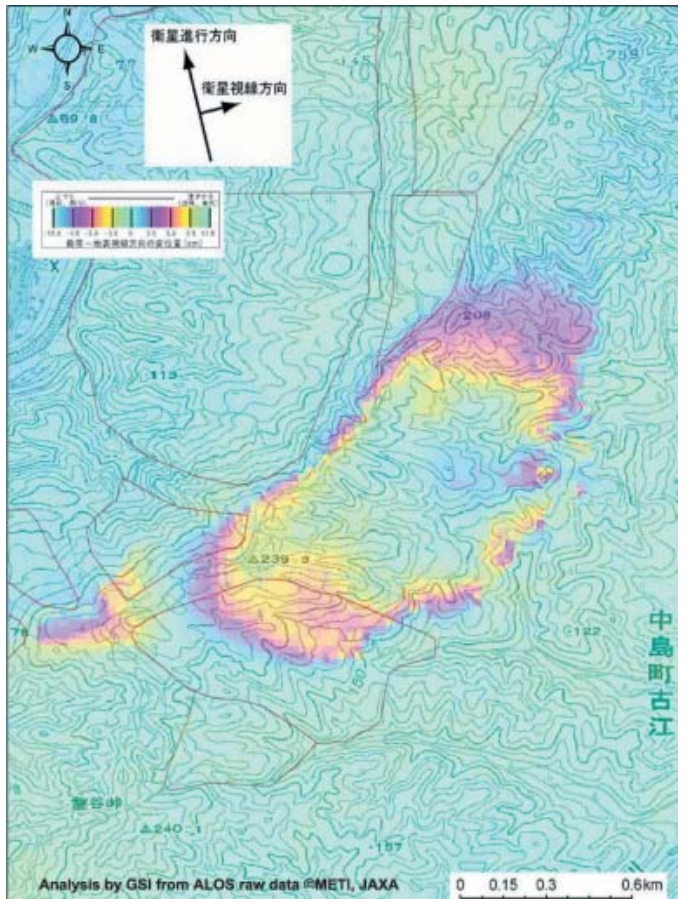

図ー 7-1 七尾市中島町古江の変動パターン

Fig. 7-1 Deformation Pattern in Furue

日に西方上空（ascending軌道）から，図-11は地震前 の2007年 1 月16日と地震後の 7 月19日に東方上空（descending軌道）から観測されたPALSARのデータをそ れぞれ用いて作成されたSAR干渉画像である。特にdescending軌道からの観測で，震源近傍の観音岬付近を中 心にした楕円形の干渉縞が明瞭に現れ，震源断層による 広域的な地殼変動を示している。なお， ascending軌道 に現れている，震源からやや離れた帯状の変動は，活褶 曲が成長したことを示していると考えられる（国土地理 院，2007d, Nishimura et al. 2008)。能登半島地震と同

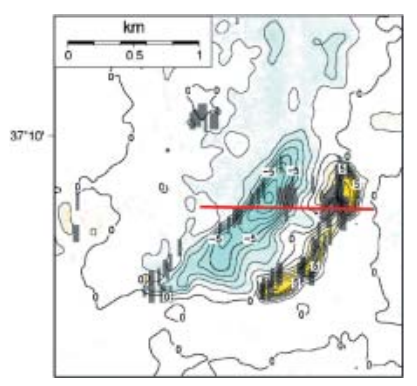

図-7-2 上下方向の 変動量 (水 色：低下, 黄色：隆 起)。赤 線 は図 - $7-$ 4 の断面位 置。

Fig. 7-2 Vertical component of deformation

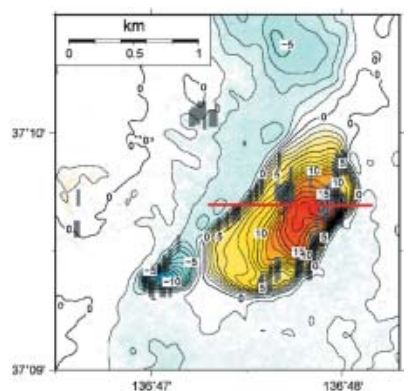

図-7-3 東西方向の

変動量（水

色：西方向, 黄〜赤：東 方向）。赤 線は図 -7 - 4 の断面 位置。

Fig. 7-3 East - west component of deformation



図ー 7-4 東西断面の地表変動ベクトル

Fig. 7-4 Surface Deformation Vectors

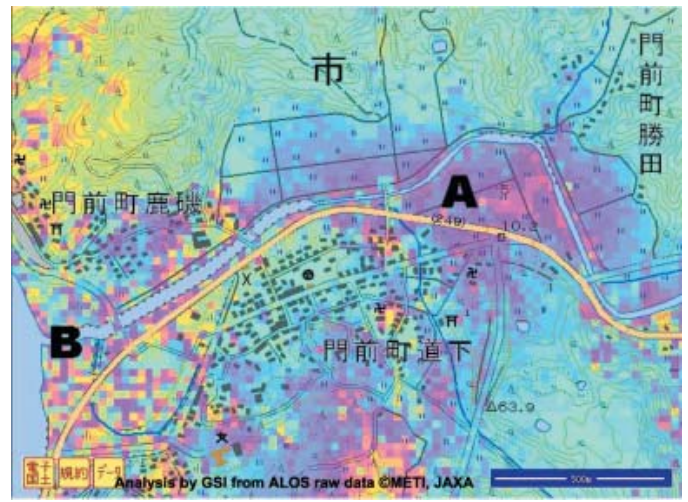

図ー8 輪島市門前町道下付近の変動パターン。Aは沖積層 の沈下, Bは砂丘の変形を示す。

Fig. 8 Deformation pattern in Toge

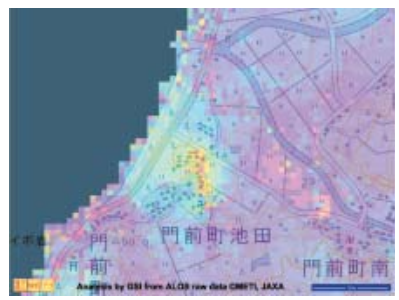

図－9＼cjkstart輪島市門前町池 田付近の変動パ ターン

Fig. 9 Deformation pattern in Ikeda

様に，これらの画像をもとに地殼変動差分画像を作成し， 詳細に判読を行った。その結果，能登半島地震の際のよ うな地すべりを示す特徵的な変動パターンは見あたらな 
かった。しかし，被害の著しかった柏崎市街地周辺をさ らに詳細に観察すると，いくつかの特徴的な変動パター ンがみられた。これらを，地形分類や被害分布(図－12), 現地調査の結果などと合わせて，変動の要因を検討した (図-13)。その結果，次のような特徴が明らかになった。 なお，図－13はascending軌道（東方上空）の観測デー 夕から作成した差分画像である。また，下記の1) (8)は 図－13の中の(1)〜8に対応している。

(1) 被害の著しかった市街地中心部（通称えんま通り） の南側に東西方向の帯状の変動パターンが見られる。 よく観察すると周辺の水色から帯の中心に向かって黄 〜赤に変化していることから，衛星方向に近づいたと 判断でき，隆起したことを示すと考えられる。

(2) 市街地が立地している砂丘上に, 北西に向かって青 から赤〜黄に変化する変動パターンが確認され，地盤 の北西方向への移動と考えられる。

(3) (1)の崖の南の沖積低地に, (1)とは逆の青〜赤〜黄を 示すパターンが認められ，地盤の西方向への移動と考 えられる。

(4) 市街地の東の沖積低地には, 円形の中央に向かって 青〜赤〜黄と変化する変動パターンが認められ，地盤 の局所的な沈下を示しているとみられる。

(5) 沖積低地には黄〜赤〜青のパターンも認められ, 衛 星に近づく変動であることから，東方向への移動と考 えられる。

(6) 鯖石川が砂丘を浸食して形成した低地では，さまざ まな色の画素が不規則に入り乱れ，干渉画像が得られ ていない。ここでは現地で大規模な液状化が確認され ている。

(7) 市街地の東の沖積低地では, 帯状に干涉画像が得ら れていない地域があり，液状化や地盤の流動を示して いると考えられる。その範囲は沖積低地に載る薄い自 然堤防の位置と一致する。

(8)市街地の南西の段丘面に楕円状の変動パターンが認 められ，中心に向かって黄〜赤〜青と変化しているこ とから，楕円形の隆起があったことになる。

これらについて，現地調査の結果等と併せてその変動 の原因について考察した。

・ (1)の隆起パターンが現れたのは砂丘南縁の直線状の崖 の基部にあたる。砂丘の末端が最大傾斜方向の南側の 沖積低地側に側方流動したことにより，基部が圧縮変 形したと考えられる。

・市街地北部は砂丘が海側に向かって緩やかに北西方向 に傾き下がっている。(2)の変動は, 砂丘砂が地震に伴っ て傾斜方向に側方流動したことを示していると考えら れる。

・ (3)〜 (5)については, 地下水位の高い沖積層の液状化や 側方流動により発生したことが考えられる。

・砂丘を浸食して形成された低地は，砂層である上に地

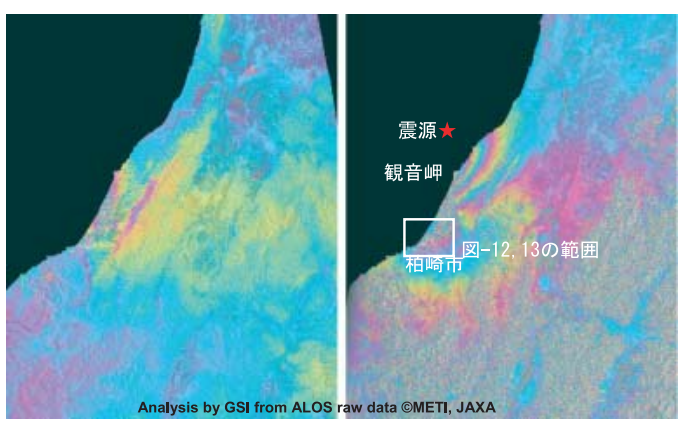

図一10 中越沖地震に伴う 地殼変動を示す SAR干渉画像。西 方上空より観測。

Fig. 10 Interferogram from ascending orbit

図-11 中越沖地震に伴う 地殼変動を示す SAR干渉画像。東 方上空より観測。

Fig. 11 Interferogram from descending orbit

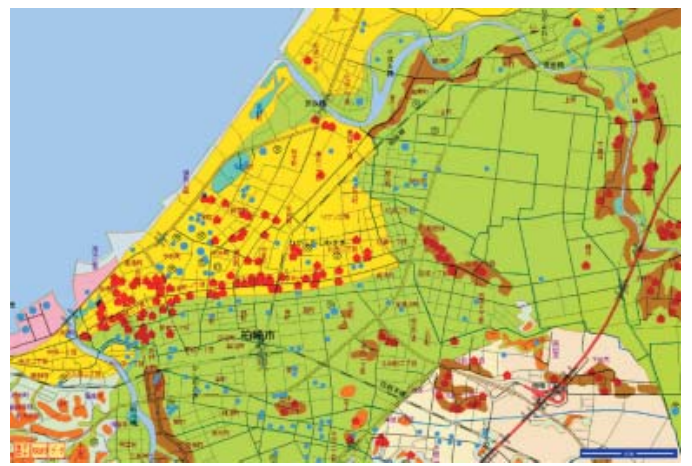

図-12 柏崎市街地の地形分類と被害分布。黄緑：低地，谷 底平野, 黄 : 砂丘, 茶：自然堤防, 薄茶 : 扇状地, 橙：段丘, 桃：埋め立て地。赤：建物の倒壊が卓越 した筒所，青：液状化が卓越した箇所

Fig. 12 Landform classification and damage map

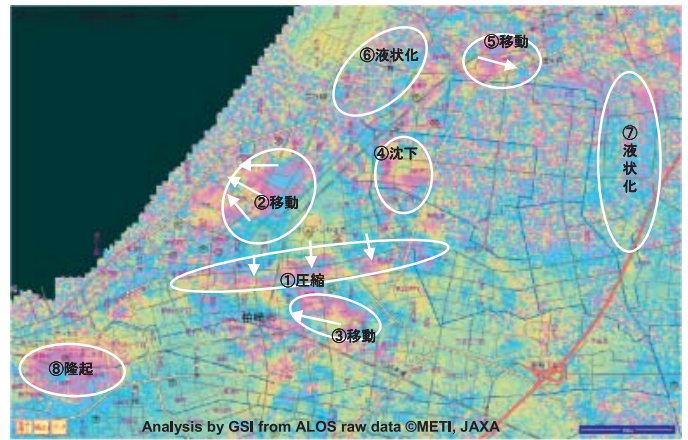

図一13 柏崎市街地の地殼変動とその解釈

Fig. 13 Deformation and its interpretation

下水位が高いことから，液状化や地盤流動が容易に発 生すると考えられる。このため，不規則な地表変動が 生じ，6のように干渉画像が得られなかったものと考 えられる。

・本地域の沖積低地上の自然堤防は，砂が沖積層上に薄 く堆積していると考えられ，軟弱な沖積層のふたをす るような状態にあり，(7)に示された地盤変動が発生し たと考えられる。

・8の隆起の原因については不明である。 


\section{2 沖積層や砂丘の変形と被害}

能登半島地震や中越沖地震でみられた地盤の側方流動 は，1983年 5 月26日に発生した日本海中部地震（M7.7） でも報告されている。例えば能代市では，砂丘が沖積低 地や後背低地と接する付近で家屋などに著しい被害が生 じ，そのような場所は地下水位が高くまた砂丘の柔らか なかつ均質な砂粒子のため液状化現象が生じやすいこと が指摘されている（国土地理院，1984）。また，砂丘縁 の約 $30^{\circ}$ の斜面では，砂丘を取り巻くように等高線にほ ぼ平行して亀裂（群）が発達し，地盤が低地側に滑って いること，噴砂・噴水を伴わないことから，液状化現象 というよりも地震動により重力的に不安定となって滑落 したことを報告している。

日本海中部地震では, 傾斜 $1^{\circ}$ の砂丘堆積物の斜面が $2 \sim 3 \mathrm{~m}$ 移動したことが報告されている。このような事 例は特殊な場合と考えられてきたが，微小な変動を面的 に捉えることができるSAR干渉画像で，地震時に沖積 低地や砂丘の微小な側方流動が広範に発生している可能 性が示唆されたということができる。

\section{4. まとめ}

「だいち」のSAR干渉画像は，その干渉性と分解能の 高さにより，これまでの調査手法では捉えることが難し かった微小な地すべり性の変動や地表地盤の変形を，高 い精度で面的，網羅的に捕捉していると考えられ，さら なる監視や防災対策立案のための，きわめて有効な情報 を提供していると考える。

一方で，地形の変化量が大きすぎると変動をSAR干 涉画像で捉えることはできず，PALSARの解像度は $10 \mathrm{~m}$ であるが，少なくとも $100 \mathrm{~m}$ 程度以上の範囲が一様に周 辺と異なる動きをしなければ干渉を得ることができない。 また，画素間の変動量の差が数 $10 \mathrm{~cm}$ 超えると干渉を 得ることはできない。また，干渉画像は衛星視線方向の 変化のみを捉えていることも，判読の際に留意する必要 がある。このような特性を踏まえて，SAR干渉画像に よる調査は, 従来から行われてきた地表踏査や空中写真 判読などと相互補完的に行われる必要がある。

今後，SAR干涉画像による調査の手法について，新 たな解析手法や事例研究を進め, 地表変動の把握手法や, 他の調査手法との組み合わせについてのマニュアル化を 図る必要がある。

\section{謝辞}

本研究で使用したALOS PALSARのデータは，国土 地理院 - 宇宙航空研究開発機構 (JAXA) 間の共同研究 協定に基づき提供されたものである。

\section{引用文献}

雨貝知美・和田弘人・藤原みどり ・鈴木 啓 - 飛田幹男 - 矢来博 司 (2007)：衛星合成開ロレーダーを用いた平成19年 (2007年)
能登半島地震に伴う地殼 - 地盤変動の検出, 国土地理院時報, 第113集，pp. 3-11.

防災科学技術研究所（2007）：地すべり分布図データベース。 http : //lsweb1.ess.bosai.go.jp/jisuberi/jisuberi_mini/index. asp

Fujiwara, S., Nishimura, T., Murakami, M., Nakagawa, H., Tobita, M. and Rosen, P. A. (2000) : 2.5-D Surface Deformation of M6.1Earthquake Near Mt Iwate Detected by SAR Interferometry, Geophys. Res. Lett., Vol. 27, pp. 2049-2052.

Hilley, G. E., Burgmann, R., Ferretti, A., Novali, F. and Rocca, F. (2004) : Dynamics of Slow-Moving Landslides from Permanent Scatterer Analysis, Science, Vol. 304, pp. 1952-1955.

石川県（1991）：土地分類基本調査「穴水・富来・剣地」，46p.

地震調査研究推進本部 (2008)：2007年の主な地震活動の評価, http ://www.jishin.go.jp/main/chousa/major_act/act_2007. $\mathrm{htm}$.

小荒井 衛 - 宇根 寛 - 西村卓也 - 矢来博司 - 飛田幹男 - 佐藤 浩（2008）：SAR干渉画像で捉えた平成19年（2007年）新潟 県中越沖地震による地盤変状と活褶曲の成長, 地質学雑誌.

国土地理院（1984）：1983年日本海中部地震調查図，国土地理院技 術資料D · $1-$ No. 255 .

国土地理院（2007a）：人工衛星デー夕を用いて硫黄島の地殼変動 を詳細に把握, http ://www.gsi.go.jp/WNEW/PRESSRELEASE/2007/0309-1.htm

国土地理院（2007b）：人工衛星デー夕を用いて平成19年（2007年） 能登半島地震に伴う地殼変動を詳細に把握, http ://www.gsi. go.jp/WNEW/PRESS-RELEASE/2007/0412.htm

国土地理院（2007c）：人工衛星デー夕を用いて平成19年（2007年） 新潟県中越沖地震に伴う地殼変動を面的に把握（第 1 報）, http : //www.gsi.go.jp/WNEW/PRESS-RELEASE/2007/0720 b.htm

国土地理院 $(2007 \mathrm{~d})$ ：人工衛星データの解析により平成 19 年 $(2007$ 年) 新潟県中越沖地震に関連した地凯変動を新たに発見，http //www.gsi.go.jp/WNEW/PRESS-RELEASE/2007/1002.htm

国土地理院（2008）：国土地理院干渉SARホームページ, http ://vldb.gsi.go.jp/sokuchi/sar/

Nishimura, T., Tobita, M., Yarai, H., Amagai, T., Fujiwara, M., Une, H., and Koarai, M.(2008) : Episodic Growth of Faultrelated Fold in Northern Japan Observed by SAR Interferometry, Geophys. Res. Lett., Vol. 35, L13301, doi : 10. 1029/ 2008 GL034337.

小沢慎三郎 - 矢来博司 - 飛田幹男 - 宇根 寛 - 西村卓也 (2007）： 平成19年（2007年）能登半島地震の震源断層モデル，国土地 理院時報，第113集，pp. $49-54$.

Ozawa, S., Yarai, H., Tobita, M., Une, H. and Nishimura, T. (2008) : Crustal Deformation Associated with the Noto Hanto Earthquake in 2007 in Japan, Earth Planets Space, Vol. 60, pp. $95-98$.

Refice, A., Guerriero, L., Bovenga, F., Wasowski, J., Veneziani, N., Atzori, S., Ferrari, A. R. and Marsella, M.(2000) : Detecting Landslide Activity by SAR Interferometry, Proceedings of the 2000 ESA ENVISAT Symposium, http://earth.esa.int pub/ESA_DOC/gothenburg/207 refic.pdf

関口辰夫 ・ 藤原 智 - 飛田幹男 - 矢来博司 · 大井信三 (2005)：干 渉SARによる地すべりの検出と地形との関係，日本地理学会 発表要旨集, No.68, pp. 95.

清水孝一 ・山越隆雄 - 小山内信智 - 福嶋 彩 • 三尾有年（2005） 合成開口レーダの差分干渉処理技術による地すべり地検知の 可能性について, 日本地すべり学会誌, Vol. 42, No. 4, pp. 32 -37 .

矢来博司 · 大井信三 - 関口辰夫 · 飛田幹男 - 藤原 智 $(2004)$ : JERS - 1/SARデータの干渉解析による火山地域の地すべり 変位の検出, 平成16年度東京大学地震研究所共同利用（研究 集会)「干涉SARの展開」(課題番号：2004-W-09).

（原稿受付2007年12月13日，原稿受理2008年 5 月 12 日） 